\title{
Periodontal link in forensic research - An overview
}

\author{
S. Gopalakrishnan ${ }^{1 *}$, Gomathi G $D^{2}$, Vivekanandan $\mathrm{U}^{3}$, M Sharmila ${ }^{4}$ \\ ${ }^{1}$ Professor, ${ }^{2,4}$ Post Graduate, ${ }^{3}$ Senior Lecturer, ${ }^{1,2}$ Dept. of Periodontics, ${ }^{3,4}$ Dept. of Orthodontics, Thai Moogambigai Dental \\ College \& Hospital, Chennai, Tamil Nadu, India
}

*Corresponding Author: S. Gopalakrishnan

Email: gopalakrishnan_perio@ymail.com

\begin{abstract}
Forensic Dentistry is defined as a budding branch of dentistry dealing with dental evidence for human identification. Periodontal tissues are the supporting apparatus of the tooth which has many hidden genetic components that could be useful in the field of Forensic science. This article highlights the importance of periodontal tissues in various aspects of forensic research.
\end{abstract}

Keywords: Forensic research, Periodontal tissues.

\section{Introduction}

Forensic dentistry is a stream of forensic science that explores dental evidences like case records, bitemarks, lip print, tooth morphology, palatal rugae pattern and periodontal tissues patterns for comparing the ante mortem and postmortem records. ${ }^{1}$ An ante mortem record contains written case sheets, past dental and medical histories, radiographs, photographs, study models, drug list and other vital information about periodontal tissues. Periodontal tissue remains even when the deceased is buried, decomposed or cremated that are used in identifying the victim or a suspected person. ${ }^{2}$

The first case of odontological evidence in forensics was Lollia Paulina's case which was identified from her discolored front tooth. ${ }^{3}$ In 1775, Dr. Joseph Warren was killed in a war at Bread Hill in England whose body was identified using his dental fillings. His body was identified by Dr. Paul Revere from the dental amalgam fillings \& ivory bridge. This was the first recorded medico-legal identification case. ${ }^{4}$ In 1758 , another case was identified using dental evidence. Peter Halket, a French soldier was killed during Indo French war. His body was identified by his son with the aid of his artificial tooth. On May 4, 1897, a fire accident occurred at Paris in the Bazaar de la Charité. Almost 1200 people died in the disaster. Many deceased were identified using periodontal structure as evidence. This was the first Mass disaster identification done by Forensic odontology. The first discourse on Forensic Odontology was carved by Dr. Oscar Amoedo, also known as father of Forensic Odontology wrote first book in 1898, entitled L'Art Dentaire en Medicine Legale. ${ }^{5}$ The first forensic identification in India started in around 1193 where Jai Chand was identified by his false teeth. ${ }^{6}$

\section{Periodontal link in forensics}

Periodontology is defined as the study of periodontium in health and disease that could be utilized for identification of victims through anatomy and pathology. The periodontal structure of each patient is unique that could help in identifying the individual. Changes in color contour, consistency, surface texture, position, interproximal craters, bone pattern could be matched with ante mortem records to establish the identification of an individual. The clinical parameters of the periodontal ligament such as widening of periodontal ligament, lateral periodontal cysts and periodontal abscess have been taken into consideration for establishing identity of the individuals. ${ }^{7}$

\section{Determining time of death}

Periodontal tissues are highly vascular in nature with enormous mitotic cellular activity. After death there are several changes in the tissues which start within minutes and lasts upto many hours. The decomposition initiates within $15 \mathrm{~min}$ and progresses with time. The autolytic activity starts in the superficial layer and gradually progresses to the basal layer. Basal layer has high mitotic activity and is composed of stem cells and progenitor cells. The histological changes observed in the gingival tissues at different time intervals are chromatin clumping, nuclear vacuolation, karyopyknosis, prominent and widened intercellular junction, homogenization and loss of epithelial architecture. Decrease in the cell activity reveals the approximate time of death. These histological 
changes occurring in the gingival tissues of the deceased can be used to determine the time of death. ${ }^{8}$

\section{Sex determination}

DNA from the gingival cells [Fibroblasts, endothelium, undifferentiated mesenchymal cells] of an individual could be utilized by Sex determining Region-Y (SRY) gene amplification using RT-PCR for gender determination. ${ }^{9}$ Changes in the nuclear: Cytoplasmic ratio values helps in identifying gender of the patient. ${ }^{10}$

\section{Age estimation}

Cementum is deposited continuously throughout the lifetime of a person. Deposition of cementum occurs in layers. These incremental lines increase with age. These incremental lines are counted in ground section. Cemental incremental lines can be used for age estimation of the deceased. ${ }^{11}$

Skull is the most commonly found bone in human remains and sometimes the only bone available. The changes in alveolar bone help in estimating the age of a person that begins at approximately 30 years and is consequential at approximately 50 years. The association of alveolar bone loss with age does not inevitably reflect the process of aging but also depicts behavioral changes (hygiene, hormonal impregnation, and tobacco) on the periodontal tissues. Alveolar bone loss is greater in Periodontitis, which forbids the application of the alveolar bone as a factor in forensic analysis. ${ }^{12}$

The neurovascular elements transit to supply teeth and supporting structures through vascular/ nutrient canals in bone. These are present in mandibular anterior region followed by premolar and maxillary sinus. ${ }^{13}$ Studies have suggested that nutrient canals ratio altered with respect to gender. With respect to age and gender, female showed maximum nutrient canals at 31- 40 years of age while males had maximum nutrient canals at 2130 years of age. ${ }^{14}$

\section{Implants in forensics}

Use of implants in the field of forensics is one of the leading edge that needs further pursuit. Though implants are identical and not customized, they have batch and serial number engraved. Implants are corrosion resistant with high melting point. Implants are embedded into bone by the process of osseointegration. In case of missing or deceased, the implants remains even after cremation which could be helpful in identification of the victim. $^{15}$

\section{Conclusion}

Though Periodontium has rich source of evidence as that of tooth but it is usually unfocused. Utilizing periodontal evidences and records could serve as antemortem evidence. It is essential to bring the important hidden aspect of tooth supporting apparatus in the field of Forensic odontology to light that could aid during various crucial periods.

\section{Source of funding}

None.

\section{Conflict of interest}

None.

\section{References}

1. Acharya $A B$, Sivapathasundaram B. Forensic odontology. In: Rajendran R, Sivapathasundaram B, editors. Shafer's Textbook of Oral Pathology. $6^{\text {th }}$ ed. India: Reed Elsevier India Pvt. Ltd.; 2009. p. 871-99.

2. Nadeem Jeddy, Shivani Ravi \& Radhika. T. Forensic trends. J Forensic Dent Sci 2017;9(3):115-9.

3. Dorion RB. New York: Marcel Dekker; 2005. Bitemark Evidence.

4. Dio C, Earnest C, Baldwin HF. London: W. Hememamm; 1914. Dio's Roman History.

5. Hunter WW. 2nd ed. London: Trubner and Co; 1885. The Imperial Gazetteer of India.

6. Grady R. Personnel identity established by the teeth: The dentist as a scientific expert. Am J Dent Sci 1884;17:384405.

7. Shamim T. Periodontics perspective in identification and age estimation. Eur J Forensic Sci 2014;1(1):18-22

8. Yadav AB, Angadi PV, Kale AD, Yadav SK. Histological assessment of cellular changes in postmortem gingival specimens for estimation of time since death. J Forensic Odonto-stomatol 2015;33(1):19-26

9. Patel PV, Kumar S, Kumar V, Vidya G. Quantitative cytomorphometric analysis of exfoliated normal gingival cells. J Cytol 2011;28:66-72.

10. Kavitha R. Molecular techniques in forensic dentistry. $J$ Forensic Odontol 2008;1:13-7.

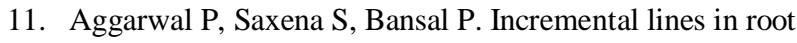
cementum of human teeth: An approach to their role in age estimation using polarizing microscopy. Indian J Dent Res 2008;19:326-30

12. Michel Ruquet, Berengere Saliba-Serre, Delphine Tardivo, Bruno Foti. J Forensic Sci 2015;60(5):1305-9.

13. Harorli A, Yilmaz AB, Akgül HM. Interpretation of radiography. Fundamentals of Radiology and 
Radiodiagnostics in Dentistry. $1^{\text {st }}$ ed. Erzurum: Atatürk University; 2001. p. 217-46.

14. Prashant Gupta, Shantala R Naik, Alpana Tiwari, Madhuri Gupta. Nutrient Canals of the Alveolar Process as an Anatomical Feature for Age and Gender Determination. $J$ Forensic Odontol 2017;29 (4):358-61.

15. Deepti Rakesh Gattani and Snehal Prabhakar Deotale. Forensic dentistry: Adding a perio 'scope' to it. J Indian Soc Periodontol 2016;20(5):485-7.

How to cite this article: Gopalakrishnan S, Gomathi GD, Vivekanandan U, Sharmila M. Periodontal link in forensic research - An overview. Int Dent $J$ Student Res $2019 ; 7(4): 81-3$. 